\title{
The Development of Life Skills Based Instructional Model at Training and Education Centre
}

\author{
Sri Rahayu ${ }^{1 *}$, Abdul Muin Sibuea ${ }^{2}$, Julaga Situmorang ${ }^{3}$ \\ ${ }^{1)}$ Educational Technology, Postgraduate Program, Universitas Negeri Medan, Indonesia \\ ${ }^{2,3)}$ Educational Technology, Universitas Negeri Medan, Indonesia \\ *srir99774@gmail.com
}

\begin{abstract}
This study aims to produce a life skills based instructional model which is properly used in English instruction, and also to know the effectiveness of the life skills based instructional model. This study belongs to a research and development which uses the R\&D model by Borg and Gall and combined with the instructional design model by Dick and Carey. The research methodology consists of two phases. Phase I is to develop the learning media and trial process, phase II is to test the effectiveness of the product. In the phase of validity and trial process, the instructional model is very proper to be used in learning English at training and education centre. In the phase of effcetiveness test, the model is very effective to be used as instructional model in learning English for general English students at training and education centre.
\end{abstract}

Keywords: life skill, instructional model, education and training centre

\section{Introduction}

The development of science and technology makes the change and tight competition globally. To compete globally, we must develop and improve the quality of human resources. One of the way to improve it is through education. The educational institute which can help to improve the competence of human resources is the training and education centre. The institute can develop people's competence based on the needs in industrial world.

In general, people think that the training and education centre (course) is more efficient socially and economically than formal school. They think that course has a better quality to win the competetion in getting job. Course can give the skills needed in getting job [1]. There are many kinds of course in Indonesia, such as English course, computer course, course of beauty, automotive course, cooking course, sewing course, etc. The course can be followed by everyone of any levels, either students or workers.

People will obtain life skills based on the course they joined, so thet can compete healthily to get a job in order to improve their life [2]. However, there are so many problems that cause the training and education centre can not run their function well. The alumnus of courses can not get the competence which is needed by the companies. The cause is that the training and education centre does not provide the appropriate curriculum, media, instructor and infrastructures. English course is one the popular course in Indonesia. There are many training and education centres provide English course. Unfortunately, many of them can not produce the alumnus who master all skills in English, such as listening, speaking, reading and writing. Based on the observation done in three areas in North Sumatera, the manager of the training and education centre said that they do not have basic curriculum for English course, 
so it is hard for them to develop the appropriate instructional model and media which can support the instructional process in English course.

Based on that problem, the researcher was interested to develop a life skills based intsructional model in English course. Instructional model is an accurate representation as an actual process which enables someone or a group of people to act based on that model [3]. Another opinion said that instructional model is a conceptual framework which describes the procedure sytematically in organizing the students' experience in learning to achieve the objectives of learning process [4].

The instructional model is completed by a modul which can be an intsructional media in learning English in training and education centre. The instructional model can improve students' skills especially in English so they can use them in industrial world. Life skill is the skills and braveness to face the problems in life, then they find the solution actively and creatively to solve the problems [5]. Another one said that life skill shows the skills which are obtained through training and experience [6]. The concept of life skills was included in developing the instructional model.

The name of the developed life skills based instructional model is RAYISAH. The model has seven activities of learning. They are: (1) Refresh, (2) Analysis, (3) Yardstick, (4) Integrity, (5) Soft skill, (6) Acceptance and (7) Hard skill. The objectives of this research and development are: (1) to develop a proper life skills based instructional model in learning English at training and education centre in North Sumatera; and (2) to test the effectiveness of the life skills based instructional model. The instructional model which was developed is used for students in training and education centre and it is used in learning English only.

\section{Research Method}

The method used in this study is research and development which uses R\&D model by Borg and Gall [7] and combined with instructional design model by Dick and Carey [8]. This research was conducted in two training and education centres in North Sumatera. They are Aditya Education Centre in Asahan and Alex English Course in Tanjung Balai. The subject of this research is students in general English class.

There are five steps to produce this life skills based instructional model in learning English. They are: (1) preliminary (2) planning, (3) development, (4) validation, (5) trial test. The data was analyzed by using descriptive statistic technique. The qualitative data such as "Very Proper", "Proper", "Enough", "Improper" and "Very Improper" was changed into quantitative data in the scale of 1 to 5 . The criteria of the media was converted based on Likert Scale and it was analyzed by using the pattern below:

$$
X=\frac{\text { Total Score }}{\text { Ideal Total Score }} \times 100 \%
$$

The criteria of the assessment can be seen in Table 1 .

Table 1. The Criteria of Assessment

\begin{tabular}{cl}
\hline Percentage & Criteria \\
\hline $0-20$ & Very Improper \\
$21-40$ & Improper \\
$41-60$ & Enough \\
$61-80$ & Proper \\
$81-100$ & Very Proper \\
\hline
\end{tabular}


Then, the research was continued to the effectiveness test of the product. The effectiveness test toward the product was conducted in two classes from two training and edication centres, as fllows: (1) the class which was taught by using the life skill based instructional model as the experimental class with 20 students; and (2) the class which was taught by using the conventional model as the controlled class with 20 students too. The hypothesis was tested by using two way t-test with the pattern as follows:

$$
t=\frac{\bar{X}_{1-}-\bar{X}_{2}}{s \sqrt{\frac{1}{n_{1}}+\frac{1}{n_{2}}}}
$$

The test could be conducted if the data could pass some requirements as follow: (1) data normality test by using Liliefors technique, and (2) data homogeneity test by using Fisher test.

\section{Results and Discussion}

The result of this research can be viewed from two sides: (1) the result of validity and trial test toward the life skills based instructional model and (2) the result of the effectiveness test toward the life skills based instructional model.

\section{The Validity and Trial Test toward the Product}

The life skills based instructional model which was developed in this research was validated by six experts. They are two English content experts, two instructional design experts and two instructional media experts. After the validity of the experts, the product must get trial test for the users (students) with the specification: 3 students in individual trial, 9 students in small group trial and 20 students in field trial test.

The result of English content experts toward the life skills based instructional model is very proper with the percentage of $82.94 \%$. The detail assessment can be seen in Table 2

Table 2. The Assessment of Content Experts

\begin{tabular}{clrl}
\hline No & Indicator & Percentage & Criteria \\
\hline 1. & The content & $76.67 \%$ & Proper \\
2. & The presentation & $83.33 \%$ & Very Proper \\
3. & The language & $86.67 \%$ & Very Proper \\
4. & The graphic & $95 \%$ & Very Proper \\
\hline Total & & $\mathbf{8 2 . 9 4 \%}$ & Very Proper \\
\hline
\end{tabular}

The result of instructional design experts toward the life skills based instructional model is also very proper with the percentage of $81.58 \%$. detail assessment can be seen in Table 3 .

Table 3. The Assessment of Instructional Design Experts

\begin{tabular}{clrl}
\hline No. & Indicator & Percentage & Criteria \\
\hline 1. & The content & $90 \%$ & Very Proper \\
2. & The presentation & $81 \%$ & Very Proper \\
3. & The graphic & $76 \%$ & Proper \\
\hline Total & & $81.58 \%$ & Very Proper \\
\hline
\end{tabular}


The result of instructional media experts toward the life skills based instructional model is also very proper with the percentage of $85 \%$. The detail assessment can be seen in Table 4 .

Table 4. The Assessment of Instructional Media Experts

\begin{tabular}{llrl}
\hline No. & Indicator & Percentage & Criteria \\
\hline 1. & The content & $83.33 \%$ & Very Proper \\
2. & The presentation & $84 \%$ & Very Proper \\
3. & The Audio & $86.15 \%$ & Very Proper \\
\hline Total & & $85 \%$ & Very Proper \\
\hline
\end{tabular}

Then, in individual trial, the life skills based instructional model is also in the criteria of very proper with the percentage of $81.03 \%$. The detail result can be seen in Table 5

Table 5. The Assessment of Individual Trial Test

\begin{tabular}{llrl}
\hline No. & Indicator & Percentage & Criteria \\
\hline 1. & The content & $81.33 \%$ & Very Proper \\
2. & The presentation & $80 \%$ & Very Proper \\
3. & The language & $73.33 \%$ & Proper \\
4. & The graphic & $90 \%$ & Very Proper \\
\hline Total & & $81.03 \%$ & Very Proper \\
\hline
\end{tabular}

In small group trial, the life skills based instructional model is also in the criteria of very proper with the percentage of $90.09 \%$. The detail result can be seen in Table 6 .

Table 6. The Assessment of Small Group Trial Test

\begin{tabular}{llrl}
\hline No. & Indicator & Percentage & Criteria \\
\hline 1. & The content & $89.78 \%$ & Very Proper \\
2. & The presentation & $85 \%$ & Very Proper \\
3. & The language & $94.44 \%$ & Very Proper \\
4. & The graphic & $96.67 \%$ & Very Proper \\
\hline Total & & $90,09 \%$ & Very Proper \\
\hline
\end{tabular}

The last in field trial, the life skills based instructional model is also in the criteria of very proper with the percentage of $92.08 \%$. The detail result can be seen in Table 7 .

Table 7. The Assessment of Field Trial Test

\begin{tabular}{llrl}
\hline No. & Indicator & Percentage & Criteria \\
\hline 1. & The content & $91 \%$ & Very Proper \\
2. & The presentation & $90.50 \%$ & Very Proper \\
3. & The language & $92,50 \%$ & Very Proper \\
4. & The graphic & $97.50 \%$ & Very Proper \\
\hline Total & & $92.08 \%$ & Very Proper \\
\hline
\end{tabular}

The result of validity from the experts indicated that the life skills based instructional model is very proper to be used as a model in learning English to improve their life skills. The 
model has fulfilled the standard of learning content, instructional design and instructional media. It is also appropriate with the characteristic of students as the users and it has fulfilled the students' need at training and education centre.

Instructional model contains of information and knowledge which is designed to make students being facilitated to communicate and learn [10]. Therefor, the life skills based instructional model is proper to facilitate students to learn individually or collaboratively.

\section{The Effectiveness of the Product}

The result of validity test toward the pre test data in the experimental class was obtained that $\mathrm{L}_{0}$ was lower than the value of $\mathrm{L}_{\text {table }}(0.155<0.90)$. In the controlled class was also obtained that $\mathrm{L}_{0}$ was lower than the value of $\mathrm{L}_{\text {table }}(0.187<0.190)$. It means that the pretest data both in the experimental class and controlled class had normal distribution at the significance level of 0.05 . Next, the result of validity test toward the post test data in the experimental class was obtained that $\mathrm{L}_{0}$ was lower than the value of $\mathrm{L}_{\text {table }}(0.186<0.190)$. In the controlled class was also obtained that $\mathrm{L}_{0}$ was lower than the value of $\mathrm{L}_{\text {table }}(0.149<$ 0.190). In conclusion, the post test data both in the experimental class and controlled class had normal distribution at the significance level of 0.05 .

The result of homogeneity test toward the pre-test data in the experimental and controlled class was obtained that the value of $F$ was lower than the value of $F_{\text {table }}(1.17<2.15)$, so the data in both classes had the same variance or homogenous. Then, the homogeneity test toward the post test data in the experimental and controlled class was also obtained that the value of $\mathrm{F}$ was lower than the value of $\mathrm{F}_{\text {table }}(1.14<2.15)$, so it can be concluded that the data in both classes had the same variance or homogenous.

The research could be continued to the hypothesis testing because the data was normal and homogenous. The testing was conducted by using two way t-test. It was obtained that $t_{\text {count }}=3.34$ and $t_{\text {table }}=1.68$, it means that $t_{\text {count }}>t_{\text {table }}$ at the significance level of 0.05 . Based on the result, it can be concluded that Ho was rejected meanwhile Ha was accepted. On the other words, there was a significant difference between the learning outcome of students who were taught by using the developed life skills based instructional model with the ones who were taught by using conventional model at the significance level of $5 \%$.

The effectiveness score of the developed life skills based instructional model is $80.70 \%$, whereas the effectiveness score of the conventional model is only $72.10 \%$. In conclusion, the life skills based instructional model is more effective to be used in learning English at training and education centre than the use of conventional model.

The purpose of doing this effectiveness test is to decide whether the product can be used continuously because it is effective or it is stopped because it is not effective. The effectiveness of the life skills based instructional model in learning English at training and education centre is caused by one main factor that the model could create the self directed learning at the course. It means that the students can learn English whenever and wherever. Surely, it helps students to improve their life skills in English that can support their skills in getting job easily.

Based on the effectiveness test, the life skills based instructional model can be used continously at training and education centre especially in learning English to give students skills which are needed in industrial world. 


\section{Conclusion}

Based on the result and discussion of this study, it can be concluded that the life skills based instructional model in learning English for the students at training and education centre has fulfilled the validity standard of instructional model based on the assessment of content, instructional design and media experts. Therefor, it is proper to be used as instructional model in learning English.

The use of the life skills based instructional model is effective to improve the students' learning outcome in learning English. The product can attract the students' interest in learning English through the life skills based instruction. Then, the product can be used continuously in learning English especially for students at training and education centre especially in general English class.

This research is useful as the reference for the next researchers who are interested to conduct a research in instructional model or media. For future researchers, the authors hope to conduct the similar research in wider subjects and deeper discussion.

\section{References}

[1] Komar O. (2006), Filsafat Pendidikan Formal Pustaka Setia.

[2] Triyana, Y. F. (2012), Tips Merintis dan Mengelola Berbagai Lembaga Kursus, Laksana.

[3] Suprijono, A (2011), Model-model Pembelajaran, Gramedia Pustaka Jaya.

[4] Indrawati and Setiawan, W, (2009), Pembelajaran Aktif, Kreatif, Efektif dan Menyenangkan untuk Guru SD, PPPPTK IPA.

[5] Listyono, (2011), Orientasi Life Skill dalam Kurikulum Tingkat Satuan Pendidikan dengan Pendekatan Sets, Perpustakaan UIN Sunan Ampel.

[6] Kunia, S. W, (2006), Pendidikan Keterampilan sebagai Upaya Pemberdayaan Siswa Perpustakaan UIN Maulana Malik Ibrahim.

[7] Gall, M. D., Gall, J. P., \& Borg, W. R, (2003), Educational Research: An Introduction $\left(7^{\text {th }}\right.$-Ed), Pearson Education.

[8] Dick, W., Carey, L. \& Carey, J. O, (2015), The Systemic Design of Instruction, Pearson.

[9] Sudjana, (2005), Metoda Statistika, Bandung :Tarsito.

[10] Suparman, A., (2012), Desain Instruksional Modern, Yogyakarta: Erlangga. 